\title{
Rezygnacja przez nupturientów i małżonków ze wspólności ustawowej w świetle praktyki notariuszy Łódzkiej Izby Notarialnej
}

\section{Wstęp}

$\mathrm{M}$ ałżeństwo, jako związek kobiety i mężczyzny, cieszy się szczególnym zainteresowaniem polskiego prawodawcy i znajduje się pod ochroną, o czym stanowi art. 18 Konstytucji ${ }^{2}$. Instytucji małżeństwa i rodziny ${ }^{3}$ dotyczy ustawa z dnia 25 lutego 1964 r. Kodeks rodzinny i opiekuńczy4. W art. 23 ustawa ta stanowi, że małżonkowie mają równe prawa i obowiązki. Do obowiązków ustawodawca zaliczył: zobowiązanie do wspólnego pożycia, do wzajemnej pomocy i wierności oraz współdziałania dla dobra rodziny, którą przez swój związek kobieta i mężczyzna założyli ${ }^{5}$. W literaturze wyrażany jest pogląd, że w omawianym za-

${ }^{1}$ Niniejsza publikacja stanowi przyczynek do dyskusji na temat ustrojów majątkowych małżeńskich i została opracowana na podstawie zawodowych doświadczeń autorki, która w latach 2010-2013 pracowała jako asesor notarialny w jednej z łódzkich kancelarii notarialnych, a także dzięki wykorzystaniu ankiety internetowej przeprowadzonej wśród notariuszy Łódzkiej Izby Notarialnej w październiku 2015 r., której kwestionariusz znajduje się w aneksie.

2 Art. 18 Konstytucji Rzeczypospolitej Polskiej z 2 IV 1997 r. (DzU z 1997, nr 78, poz. 483 z późn. zm.): „Małżeństwo jako związek kobiety i mężczyzny, rodzina, macierzyństwo i rodzicielstwo znajdują się pod ochroną i opieką Rzeczypospolitej Polskiej".

${ }^{3} \mathrm{Na}$ marginesie należy odnotować, że określenie „rodzina” należy do tych pojęć, które rozumiemy instynktownie. Nie budzi ono problemów interpretacyjnych w codziennym życiu i komunikacji międzyludzkiej. Analizując jednak problematykę rodziny w świetle przepisów prawa można zauważyć, że w obowiązujących regulacjach oraz w doktrynie, termin ten bywa różnie definiowany i rozumiany. Zagadnienie dotyczące definicji rodziny w polskich aktach normatywnych i doktrynie omówił M. Kosek, Pojęcie rodziny w Kodeksie rodzinnym i opiekuńczym i negatywne skutki jej redefinicji w wybranych aktach prawnych, [w:] W trosce o rodzinę. Księga pamiatkowa ku czci Profesor Wandy Stojanowskiej, Warszawa 2008, s. 229-247.

${ }^{4}$ DzU z 2015 r., poz. 2082 z późn. zm. [dalej: KRO].

${ }^{5}$ Por. K. Gromek, Kodeks rodzinny i opiekuńczy. Komentarz, Warszawa 2013, s. 97. 
kresie dochodzi do ścisłego połączenia elementów niemajątkowych z majątkowymi, np. wzajemna pomoc może polegać na udzieleniu wsparcia emocjonalnego $\mathrm{w}$ trudnych dla małżonka sytuacjach, ale też na świadczeniach pieniężnych ${ }^{6}$. Za powszechnie akceptowaną w społeczeństwie polskim możemy uznać opinię, że zbieżne zapatrywania małżonków na kwestie majątkowe są niezwykle istotne dla zgodności i trwałości związku małżeńskiego, gdyż przekładają się na bezpieczeństwo materialne stworzonej przez nich rodziny. Tej sfery najczęściej dotyczą przyjmujące formę aktu notarialnego czynności prawne dokonywane przez małżonków. Rodzaje wydawanych dyspozycji, ich zakres i treść, a przede wszystkim powody, dla których strony decydują się na ich dokonanie, odzwierciedlają sytuacje i problemy, z którymi zmagają się polskie rodziny.

\section{Wspólność ustawowa}

Jedną z najczęściej dokonywanych czynności z zakresu prawa rodzinnego majątkowego jest zawarcie między małżonkami lub nupturientami umowy majątkowej małżeńskiej. Za jej pomocą strony mogą zmodyfikować lub wyłączyć ustawowy ustrój majątkowy, jakim jest wspólność ustawowa $^{7}$. Zgodnie z art. $31 \S 1 \mathrm{KRO}$ z chwilą zawarcia małżeństwa powstaje między małżonkami z mocy ustawy wspólność majątkowa (wspólność ustawowa) obejmująca przedmioty majątkowe nabyte w czasie jej trwania przez oboje małżonków lub przez jednego z nich (majątek wspólny). Do wspólnego majątku należą:

${ }^{6}$ Instytucje prawa rodzinnego, red. J. M. Łukasiewicz, Warszawa 2014 [LEX nr 205309]. Por: postanowienie NSA w Warszawie z dnia 12 IV 2010 r., sygn. akt I FZ 50/10, LEX nr 619705: Wobec obowiązku wzajemnej pomocy małżonków przy podziale ról i obowiązków w rodzinie, w której skarżący nie zarobkuje z uwagi na opiekę nad dziećmi, naturalną rzeczą jest pomoc finansowa współmałżonka, a wprowadzenie rozdzielności majątkowej nie niweczy tego obowiązku.

${ }^{7}$ Istnieje możliwość wprowadzenia rozdzielności majątkowej między małżonkami na mocy orzeczenia sądu (jest to tzw. przymusowy ustrój majątkowy), ale ta droga modyfikacji ustroju majątkowego małżeńskiego nie jest objęta rozważaniami zawartymi w niniejszym artykule. Nie jest również przedmiotem niniejszej analizy sądowe wyłączenie solidarnej odpowiedzialności małżonków za zobowiązania zaciągnięte w sprawach wynikających z zaspokajania zwykłych potrzeb rodziny (art. $30 \mathrm{KRO}$ ). Zob. E. Marszałkowska-Krześ, Postępowanie nieprocesowe w sprawach osobowych i rodziny, Wrocław 2012, s. 192-194.

${ }^{8} \mathrm{Na}$ potrzeby niniejszego artykułu pomijamy kwestię rozważań nad problematyką wąskiego i szerokiego ujęcia majątku wspólnego. Podsumowanie poglądów zob.: T. Sokołowski, Swoboda intercyzy. Zakres modyfikacji matżeńskich ustrojów majątkowych, Warszawa 2013, s. 33. 
- pobrane wynagrodzenie za pracę i dochody z innej działalności zarobkowej każdego z małżonków,

- dochody z majątku wspólnego, jak również z majątku osobistego każdego z małżonków,

- środki zgromadzone na rachunku otwartego lub pracowniczego funduszu emerytalnego każdego z małżonków,

- kwoty składek zewidencjonowanych na subkoncie, o którym mowa w art. 40a ustawy z dnia 13 października 1998 r. o systemie ubezpieczeń społecznych (DzU z 2015 r., poz. 121)

- renta należna poszkodowanemu ${ }^{10}$, a także

- przedmioty zwykłego urządzenia domowego służące do użytku obojga małżonków ${ }^{11}$.

Wspólność ustawowa to reżim majątkowy, w którym małżonkowie pracując i nabywając przedmioty lub prawa, wspólnymi siłami tworzą majątek należący do nich obojga, razem „dorabiają się". Jak wskazał T. Sokołowski nie sposób nie zauważyć oddziaływania elementów osobistych każdego z małżonków na ich wspólną sytuację majątkową, np. niezdolność do pracy jednego z nich najprawdopodobniej będzie wpływała negatywnie na stan wspólnego majątku, podobnie jak niskie kwalifikacje pracownicze. $Z$ drugiej strony takie cechy, jak przedsiębiorczość, zdolności menadżerskie będą przyczyniały się do powiększania majątku wspólnego i poprawy sytuacji majątkowej obojga małżonków ${ }^{12}$. Jednak małżeństwo to nie przedsiębiorstwo i nie może być rozpatrywane jedynie w aspekcie ekonomicznym.

W literaturze wskazuje się, że środki uzyskiwane wspólnie przez parę małżeńską stanowią „, podstawę bieżącej egzystencji rodziny oraz realizacji jej dalekosiężnych celów, związanych z kolejnymi fazami rozwoju rodziny (jest to osiem faz od małżeństwa przed urodzeniem dzieci aż do wdowieństwa). Majątek umożliwia spełnianie podstawowych funkcji rodziny, nie tylko funkcji ekonomicznej, ale także innych, zwłaszcza społecznych funkcji wyznaczających oraz socjopsychicznych, w tym kulturowej i rekreacyjno-towarzyskiej"13. Środki materialne pozyskiwane przez małżonków mają

${ }^{9}$ Art. $31 \S 2$ KRO.

${ }^{10}$ Art. 33 pkt 6. Przepis ten dotyczy renty należnej poszkodowanemu małżonkowi z powodu całkowitej lub częściowej utraty zdolności do pracy zarobkowej albo z powodu zwiększenia się jego potrzeb bądź zmniejszenia widoków powodzenia na przyszłość.

${ }^{11}$ Art. 34 KRO. Przepis ten stosuje się również do przedmiotów zwykłego urządzenia domowego, które zostały nabyte przez dziedziczenie, zapis lub darowiznę, chyba że spadkodawca bądź darczyńca inaczej postanowił.

${ }^{12}$ T. Sokołowski, Swoboda intercyzy..., s. 37.

${ }^{13}$ M. Andrzejewski, H. Dolecki, J. Haberko, A. Lutkiewicz-Rucińska, A. Olejniczak, T. Sokołowski, A. Sylwestrzak, A. Zielonacki, Kodeks rodzinny i opiekuńczy. Komentarz, LEX 2013, numer 152312, komentarz do art. 31 KRO. 
wpływ nie tylko na stopień zaspokojenia podstawowych potrzeb bytowych rodziny, lecz w istotny sposób wpływają na jej rozwój, pozycję społeczną jej członków, możliwości rozwoju osobistego i zawodowego. W świetle tak sformułowanego ujęcia roli majątku rodzinnego, ustawodawca przyjął model stosunków majątkowych małżeńskich, w którym dwie osoby tworzą wspólnie majątek rodziny. W piśmiennictwie często pojawia się wręcz twierdzenie, iż ustrój wspólności ustawowej jest najbardziej zgodny z istotą małżeństwa jako ścisłej wspólnoty osobowo-majątkowej ${ }^{14}$.

Oprócz majątku wspólnego, w ustroju wspólności ustawowej wyróżnia się jeszcze dwie masy majątkowe: majątek osobisty męża i majątek osobisty żony. Ustawodawca enumeratywnie wskazał, co może stanowić majątek osobisty ${ }^{15}$ :

1) przedmioty majątkowe nabyte przed powstaniem wspólności ustawowej;

2) przedmioty majątkowe nabyte przez dziedziczenie, zapis lub darowiznę, chyba że spadkodawca bądź darczyńca inaczej postanowił;

3) prawa majątkowe wynikające ze wspólności łącznej podlegającej odrębnym przepisom;

4) przedmioty majątkowe służące wyłącznie do zaspokajania osobistych potrzeb jednego z małżonków;

5) prawa niezbywalne, które mogą przysługiwać tylko jednej osobie;

6) przedmioty uzyskane $z$ tytułu odszkodowania za uszkodzenie ciała lub wywołanie rozstroju zdrowia albo $\mathrm{z}$ tytułu zadośćuczynienia za doznaną krzywdę;

7) wierzytelności z tytułu wynagrodzenia za pracę lub z tytułu innej działalności zarobkowej jednego z małżonków;

8) przedmioty majątkowe uzyskane $z$ tytułu nagrody za osobiste osiągnięcia jednego z małżonków;

9) prawa autorskie i prawa pokrewne, prawa własności przemysłowej oraz inne prawa twórcy;

10) przedmioty majątkowe nabyte $w$ zamian za składniki majątku osobistego, chyba że przepis szczególny stanowi inaczej.

Majątkiem osobistym każdy z małżonków zarządza samodzielnie, jednak dochody uzyskiwane z takiego majątku stanowią majątek wspólny (np. nieruchomość nabyta przed zawarciem związku małżeńskiego przez jednego małżonka będzie stanowiła tylko jego własność, lecz do-

${ }^{14}$ System Prawa Prywatnego. Prawo rodzinne i opiekuńcze, red. T. Smyczyński, t. XI, Warszawa 2014, s. 256.

${ }^{15}$ Art. 33 KRO. Zob. Kodeks rodzinny i opiekuńczy. Komentarz, red. K. Pietrzykowski, Warszawa 2015, s. 276 i n. 
chód osiągany z najmu owej nieruchomości zaliczany będzie już do majątku wspólnego).

J. M. Łukasiewicz podkreśla funkcjonowanie w społeczeństwie polskim przekonania, że w czasie trwania małżeństwa wszystkie składniki majątkowe są wspólne. Autor ów napisał: „Przyglądając się uważnie społecznym wyobrażeniom na temat ustroju wspólności, można ulec wrażeniu, że małżonkowie zwykle kierują się uproszczonym przekonaniem, iż bez zawartej uprzednio intercyzy wszystko to, co posiadają oraz to, co »wypracują« trafi bez wyjątku do ich »wspólnego worka «"16. W praktyce zdarza się, że osoby, które pragną podarować nieruchomość gruntową bądź lokalową dziecku, które zawarło związek małżeński, nie chcą przekazywać swojej własności na rzecz zięcia czy synowej. Trudno im zaakceptować, że z mocy powołanego powyżej artykułu $33 \mathrm{KRO}$, przedmiot darowizny stanowi co do zasady majątek osobisty obdarowanego. Niekiedy notariusz musi kilkakrotnie tłumaczyć powyższą zasadę i jej zastosowanie, przełamując tym samym stereotyp myślenia o majątku wspólnym małżonków.

\section{Umowy majątkowe małżeńskie}

3.1. Prawodawca przewidział możliwość odejścia od rozwiązania ustawowego przez zawarcie umowy majątkowej małżeńskiej. Jest "to umowa między małżonkami dotycząca w istotnym stopniu ich przyszłej, wzajemnej sytuacji majątkowej"17. Może ona doprowadzić do jednego z następujących skutków:

- rozszerzenia wspólności ustawowej,

- ograniczenia tej wspólności,

- ustanowienia rozdzielności majątkowej,

- wprowadzenia między małżonkami ustroju rozdzielności majątkowej z wyrównaniem dorobków.

${ }^{16} \mathrm{~J}$. M. Łukasiewicz, Małżeńska współzależność majątkowa w polskim prawie cywilnym, Warszawa 2013, s. 170.

${ }^{17}$ T. Sokołowski, Swoboda intercyzy..., s. 26. Por. J. Ignaczewski, Małżeńskie ustroje majątkowe. Art. 31-54 KRO. Komentarz, Warszawa 2008, s. 182 oraz wyrok Sądu Apelacyjnego w Łodzi z dnia 7 VIII 2015 r., sygn. akt I Aca185/15, LEX nr 1808658: „Celem małżeńskiej umowy majątkowej jest ustalenie zasad, według których kształtować się mają wzajemne stosunki majątkowe małżonków, a więc uregulowanie - w granicach dozwolonych przez prawo - istnienia i zakresu wspólności ustawowej. Małżeńska umowa majątkowa stanowi podstawę umownego ustroju majątkowego małżonków. Jej celem jest ustalenie zasad, według których kształtować się mają wzajemne stosunki majątkowe małżonków". 
Taka umowa może być podpisana przed zawarciem małżeństwa ${ }^{18}$; wówczas jej działanie jest zawieszone do chwili zawarcia małżeństwa przez nupturientów. Umowę majątkową można zawierać kilkakrotnie, wprowadzając kolejne zmiany w sytuacji prawno-majątkowej stron, włączając $w$ to powrócenie do wspólności majątkowej.

Z woli ustawodawcy, umowa majątkowa małżeńska musi zostać zawarta $\mathrm{w}$ formie aktu notarialnego pod rygorem nieważności (ad solemnitatem $)^{19}$. Wiąże się z tym udział osoby trzeciej, spoza kręgu rodzinnego, to jest notariusza. Notariusz przy dokonywaniu czynności działa jako osoba zaufania publicznego ${ }^{20}$, pozostaje bezstronny i ma obowiązek dbania o interesy wszystkich uczestników czynności ${ }^{21}$. Na rejencie spoczywa obowiązek udzielenia wszelkich pouczeń i wyjaśnień stronom czynności notarialnej. Dokonanie czynności notarialnej jest możliwe wyłącznie przy akceptacji przez obie strony treści planowanej czynności oraz skutków, jakie ona zrodzi ${ }^{22}$.

Nadanie umowie formy aktu notarialnego wiąże się z kosztami, które strony muszą ponieść ${ }^{23}$. Dla wielu małżeństw nie stanowią one jednak bariery przy realizacji podjętej decyzji $\mathrm{w}$ zakresie odmiennego uregulowania ustroju majątkowego. Dane zebrane przez Ministerstwo Sprawiedliwości wskazują że coraz więcej par decyduje się na skorzystanie z możliwości zawarcia umowy majątkowej. Z „Rocznika Statystycznego Rzeczypospolitej Polskiej" z 2014 r. ${ }^{24}$ wynika nieprzerwany wzrost liczby zawieranych umów majątkowych małżeńskich:

- w 2005 r. zawarto 30000 takich umów,

$-\mathrm{w} 2010$ r. -43000 ,

- w 2012 r. -44000 ,

- w 2013 r. -48000.

${ }^{18}$ Art. $47 \S 1$ KRO. Niekiedy taka umowa przedślubna nazywana jest „,intercyzą”, dla odróżnienia od umów podpisywanych po zawarciu związku małżeńskiego. Por. T. Sokołowski, Swoboda intercyzy..., s. 27-28.

${ }^{19}$ Art. $47 \S 1$ KRO.

${ }^{20}$ Art. 2 § 1 ustawy z dnia 14 lutego 1991 roku Prawo o notariacie (DzU z 2014 r., poz. 164 z późn zm. [dalej: PrNot]).

${ }^{21}$ Art. $80 \S 2$ PrNot.

${ }^{22}$ Zob. Kodeks rodzinny..., red. K. Pietrzykowski, s. 355.

${ }^{23}$ Wynagrodzenie notariusza za sporządzenie umowy majątkowej wynosi 400 zł. Kwota ta jest powiększana o należny podatek od towarów VAT i usług oraz koszt sporządzenia wypisów z aktu notarialnego. Patrz: $§ 8$ pkt 2 Rozporzadzenia Ministra Sprawiedliwości z dnia 28 czerwca 2004 roku w sprawie maksymalnych stawek taksy notarialnej (DzU z 2013 r., poz. 237 z późn. zm.).

24 „Rocznik Statystyczny Rzeczypospolitej Polskiej” [Warszawa] 2014, s. 184. 
Coraz częstsze sporządzanie umów majątkowych potwierdzają również wyniki ankiety internetowej przeprowadzonej wśród rejentów Łódzkiej Izby Notarialnej: 57,9\% ankietowanych wskazało, że liczba umów majątkowych zawieranych $\mathrm{w}$ ich kancelarii na przestrzeni ostatnich pięciu lat wzrosła, 42,1\% podało zaś, że liczba ta pozostaje ciągle na takim samym poziomie. Żaden z ankietowanych notariuszy nie zauważył spadku liczby zawieranych umów majątkowych.

3.2. Z praktyki notarialnej wynika, że do najczęściej zawieranych umów majątkowych małżeńskich należy umowa wprowadzająca rozdzielność majątkową ${ }^{25}$ Z $\mathrm{Z}$ chwilą ustanowienia rozdzielności majątkowej wspólność ustawowa przekształca się we współwłasność w częściach ułamkowych, polegającą na tym, że każdemu z małżonków przysługuje połowa dotychczasowego majątku wspólnego i każdy z małżonków zachowuje zarówno majątek nabyty przed zawarciem małżeństwa, jak i majątek nabyty później oraz zarządza samodzielnie swoim majątkiem $\left(51^{1} \mathrm{KRO}\right)^{26}$. Jak zauważyła E. Skowrońska-Bocian: „Majątki małżonków pozostają $w$ takiej sytuacji prawnej, jak majątki osób sobie obcych" ${ }^{27}$. Małżonkowie nie muszą się informować o stanie majątku, wysokości obciążających ich zobowiązań ani uzyskiwać zgody na dokonanie jakichkolwiek rozporządzeńn ${ }^{28}$. Wbrew pojawiającym się w literaturze postulatom, aby małżonkowie pozostający $\mathrm{w}$ rozdzielności majątkowej informowali się nawzajem o stanie swych majątków osobistych oraz podejmowanych rozporządzeniach przekraczających zwykły zarząd majątkiem ${ }^{29}$, obowiązek takiego zachowania nie wynika z żadnej normy prawnej, a zaniechania $\mathrm{w}$ zakresie przekazywanych informacji nie mogą powodować prawnej odpowiedzialności małżonka.

${ }^{25}$ Wszyscy notariusze, którzy odpowiedzieli na ankietę, wskazali na rozdzielność majątkową jako ustrój najczęściej wprowadzany między małżonkami na podstawie umowy zawartej w formie aktu notarialnego.

${ }^{26}$ Sadowe Komentarze Tematyczne. Małżeńskie prawo majątkowe, red. J. Ignaczewski, Warszawa 2014, s. 197. Zdaniem K. Gromek samodzielne zarządzanie i rozporządzanie majątkiem przez każdego z małżonków na podstawie przepisu art. $51^{1}$ KRO może w praktyce budzić poważne wątpliwości, gdyż bez dokonania przez małżonków podziału majątku trudno jest precyzyjnie ustalić, do majątku którego z małżonków należy konkretny przedmiot lub prawo majątkowe. Autorka sądzi, że taki podział powinien zostać dokonany w terminie nie dłuższym niż jeden rok od ustania wspólności ustawowej. K. Gromek, Kodeks rodzinny..., s. 357.

${ }^{27}$ E. Skowrońska-Bocian, Małżeńskie ustroje majątkowe, Warszawa 2010, s. 138.

${ }^{28}$ Tamże, s. 139.

${ }^{29}$ Patrz: System Prawa Prywatnego. Prawo rodzinne..., s. 495-514; G. Jędrejek, Intercyzy. Pojęcie. Treść. Dochodzenie roszczeń, Warszawa 2011, s. 111-112. 
W piśmiennictwie prawniczym zwraca się uwagę, że „do zawarcia umowy nie jest wymagane istnienie ważnych ku temu powodów" ${ }^{\prime 30}$. Dlatego też próżno szukać w treści aktów notarialnych obejmujących interesujące nas umowy wskazówek dotyczących przyczyn podpisania przez strony dokumentu ${ }^{31}$. Powody zawierania powyższych umów są z reguły przekazywane ustnie notariuszowi w czasie rozmowy przygotowawczej przed sporządzeniem aktu notarialnego.

Nasze rozważania dotyczące najczęstszych okoliczności powodujących rezygnację z ustroju ustawowego rozpoczniemy od umowy majątkowej zawieranej przez nupturientów. Umowa przedmałżeńska występuje dużo rzadziej niż umowa zawierana w czasie trwania związku małżeńskiego, co potwierdziły odpowiedzi udzielone $\mathrm{w}$ ankiecie przez notariuszy Izby Łódzkiej32. Najczęstszym powodem zawierania intercyzy przez narzeczonych jest planowana lub prowadzona przez nich bądź jedno z nich działalność gospodarcza (tę przyczynę wskazało $89,5 \%$ ankietowanych notariuszy). Z ankiety wynika, że na drugim i trzecim miejscu znajduje się potrzeba osobistego zarządzania posiadanymi zasobami i kontrola nad nimi bez konieczności uzyskania zgody współmałżonka $(36,8 \%)$ oraz wola zabezpieczenia się przed trudnym podziałem majątku w przypadku, gdyby doszło do rozwodu $(31,6 \%)$. Duże znaczenie ma również potrzeba samodzielności i niezależności finansowej.

Na zawarcie umowy wprowadzającej rozdzielność majątkową najczęściej decydują się pary pozostające w związku małżeńskim nie dłużej niż dziesięć lat. Zwykle wymieniane są następujące przyczyny zawarcia takiej umowy majątkowej:

- potrzeba ochrony majątku wspólnego oraz majątku współmałżonka w przypadku podejmowania przez tego drugiego ryzykownych przedsięwzięć gospodarczych, np. jedno z małżonków zaciąga kredyt lub pożyczkę na rozwój swojej działalności gospodarczej, wykonuje zawód związany z osobistą odpowiedzialnością całym majątkiem ${ }^{33}$, ale również

\footnotetext{
${ }^{30}$ Sąowe Komentarze Tematyczne..., s. 197; E. Skowrońska-Bocian, Matżeńskie ustroje..., s. 137.

${ }^{31} \mathrm{Na}$ temat treści umowy majątkowej małżeńskiej zob. E. Skowron-Bocian, Małżeńskie ustroje..., s. 117-120.

${ }^{32}$ Jednocześnie z odpowiedzi udzielonych w kwestionariuszu wynika, że na przestrzeni ostatnich pięciu lat wzrosła liczba zawieranych umów przedmałżeńskich.

${ }^{33}$ Por. Art. 41, § 1 KRO: „Jeżeli małżonek zaciągnął zobowiązanie za zgodą drugiego małżonka, wierzyciel może żądać zaspokojenia także z majątku wspólnego małżonków.

$\S 2$. Jeżeli małżonek zaciągnął zobowiązanie bez zgody drugiego małżonka albo zobowiązanie jednego z małżonków nie wynika z czynności prawnej, wierzyciel może żądać zaspokojenia z majątku osobistego dłużnika, z wynagrodzenia za pracę lub z dochodów uzyskanych przez dłużnika z innej działalności zarobkowej, jak również
} 
w przypadku, gdy jeden z małżonków jest zobowiązany do świadczeń alimentacyjnych wobec dzieci z poprzedniego związku, na co uwagę zwrócił G. Jędrejek ${ }^{34}$. Odpowiedź na pytanie dotyczące ponoszenia odpowiedzialności przez współmałżonka, wynikającej z prowadzenia działalności gospodarczej nie mieści się w zakresie niniejszego artykułu ${ }^{35}$. Istotne dla naszych rozważań pozostaje przekonanie małżonków, że umowa majątkowa zapewni im bezpieczeństwo i ochronę przed wierzycielami. Zdarza się, że po przedstawieniu stanu faktycznego i prawnego oraz zestawieniu go z normami wynikającymi z prawa rodzinnego, rejent dochodzi do wniosku, że nie istnieje zagrożenie dla majątku wspólnego, a tym bardziej dla majątku osobistego tego z małżonków, który nie prowadzi działalności gospodarczej. Mimo to stawający decydują się na zawarcie umowy majątkowej na zasadzie „dmuchania na zimne”. Zdarza się również, że to wierzyciel - bank stawia wymóg zawarcia umowy majątkowej jako warunek udzielenia kredytu, co ma poprawić zdolność kredytową kredytobiorców;

- istniejący konflikt między małżonkami, który może dotyczyć tak spraw majątkowych, jak i spraw osobistych. Może on skutkować podjęciem decyzji o życiu w separacji (faktycznej bądź prawnej), ale bez decydowania się na rozwiązanie małżeństwa przez rozwód, np. z powodów religijnych ${ }^{36}$;

z korzyści uzyskanych z jego praw, o których mowa w art. 33 pkt 9, a jeżeli wierzytelność powstała w związku $\mathrm{z}$ prowadzeniem przedsiębiorstwa, także z przedmiotów majątkowych wchodzących w skład przedsiębiorstwa.

§ 3. Jeżeli wierzytelność powstała przed powstaniem wspólności lub dotyczy majątku osobistego jednego z małżonków, wierzyciel może żądać zaspokojenia z majątku osobistego dłużnika, z wynagrodzenia za pracę lub z dochodów uzyskanych przez dłużnika z innej działalności zarobkowej, jak również z korzyści uzyskanych z jego praw, o których mowa w art. 33 pkt 9".

Na tę przyczynę podpisywania aktów notarialnych wskazało 100\% notariuszy Izby Notarialnej w Łodzi.

${ }^{34}$ G. Jędrejek, Intercyzy. Pojęcie..., s. 104. Autor odwołuje się do stanowiska zaprezentowanego przez A. Damasiewicza, Intercyzy i umowy między konkubentami. Klauzule umowne, Warszawa 2008, s. 88.

${ }^{35}$ Zagadnienie to omawia m.in.: M. Łączkowska, Stosunki majątkowe między przedsiębiorca i jego małżonkiem w świetle ustroju wspólności ustawowej, Warszawa 2006; J. M. Łukasiewicz, Małżeńska wspótzależność..., s. 156-161; A. Pokora, Odpowiedzialność majątkowa matżonków i przymusowe dochodzenie od nich roszczeń, Warszawa 2014; E. Skowrońska-Bocian, Rozliczenia majątkowe matżonków w stosunkach wzajemnych $i$ wobec osób trzecich, Warszawa 2005, s. 81-151.

${ }^{36}$ G. Jędrejek, Intercyzy. Pojęcie..., s. 105. E. Holewińska-Łapińska zwróciła uwagę, że małżonkowie oczekuja że umowa wprowadzająca rozdzielność zakończy trwające między nimi spory na tle majątkowym, E. Holewińska-Łapińska, Orzekanie separacji, Warszawa 2006, s. 121-122. W tym miejscu należy zauważyć, że jeżeli małżonkowie przed 
- długotrwałe postępowanie w sprawach o rozwód przed polskimi sądami sprzyja podejmowaniu przez osoby, które nadal formalnie pozostają w związku małżeńskim, decyzji o zawarciu umowy wprowadzającej rozdzielność majątkową. Pozwala ona na dokonanie podziału majątku wspólnego jeszcze przed orzeczeniem rozwodu, usamodzielnienie się ekonomiczne i odcięcie się od dotychczasowego partnera życiowego. Warunkiem jednak zawarcia takiej umowy jest brak sporu między małżonkami w zakresie spraw majątkowych. Przykładem może być para małżonków w rzeczywistości funkcjonujących oddzielnie - mieszkają w osobnych domach, mają oddzielne rachunki bankowe i sporadycznie się ze sobą kontaktują. Sytuacja taka trwa zazwyczaj do czasu, gdy jedno z nich pozna nowego partnera i zapragnie z nim np. kupić wspólnie nowe mieszkanie. Uniemożliwia to pozostawanie w ustroju wspólności ustawowej z dotychczasowym współmałżonkiem. Osoby takie mogą podpisać umowę wprowadzającą rozdzielność majątkową za obopólnym porozumieniem, a następnie wystąpić do sądu o orzeczenie rozwodu. W ten sposób jeszcze przed wyrokiem rozwodowym następuje usankcjonowanie istniejącego rozkładu więzi gospodarczej. W ankiecie jeden $z$ notariuszy Izby Łódzkiej wskazał, że to głównie małżeństwa z długim stażem decydują się na zawarcie umowy majątkowej przed lub w toku rozwodu;

- kolejną przyczyną jest zagwarantowanie każdemu z małżonków niezależności i samodzielności pod względem ekonomicznym. W tym zakresie możemy wymienić również potrzebę osobistego zarządzania posiadanymi zasobami i kontrolę nad nimi, jak i zachowania majątku zgromadzonego przed zawarciem małżeństwa oraz jego konsumpcję ${ }^{37}-$ może ona być związana z cechami osobowymi i określonym poglądem na stosunki majątkowe małżeńskie lub wynikać z przyczyn obiektywnych, do jakich należy życie małżeństw w rozłące spowodowanej emigracją zarobkową ${ }^{38}$;

- z praktyki notarialnej wynika, że powodem wprowadzania ustroju rozdzielności majątkowej jest również brak zaufania do współmałżonka.

separacją pozostawali w ustroju wspólności ustawowej, to orzeczenie separacji powoduje powstanie między nimi rozdzielności majątkowej (art. 54 § $1 \mathrm{KRO}$ ).

${ }^{37} \mathrm{Nad}$ problemem konsumpcji w rodzinie pochyliła się M. Miczyńska-Kowalska, Konsumpcyjny charakter rodziny w społeczeństwie ponowoczesnym, [w:] Małżeństwo i rodzina w ponowoczesności. Szanse-zagrożenia-patologie, red. W. Muszyński, E. Sikora, Toruń 2008, s. 133-141.

${ }^{38}$ Wiele małżeństw podejmuje decyzję o życiu w rozłące $\mathrm{w}$ ten sposób, że jedna osoba emigruje do innego kraju w poszukiwaniu lepszych zarobków, druga zaś zostaje z dziećmi w Polsce. W takiej sytuacji rozdzielność majątkowa wydaje się praktycznym rozwiązaniem, umożliwiającym sprawne zarządzanie masami majątkowymi należącymi do każdego z małżonków. 
Może on przybrać postać braku zaufania co do rodzaju i sposobu prowadzonej przez współmałżonka działalności zawodowej, wydawania pieniędzy lub nieufności wobec współmałżonka, obawy przed wykorzystaniem ekonomicznym, a nawet oszukaniem. W literaturze jako przykład powodu zawarcia przez małżonków umowy majątkowej małżeńskiej, wskazano sytuację, gdy jeden małżonek ,jest skąpy albo obawia się, że współmałżonek będzie korzystał z majątku wspólnego w celu wspomagania dorosłych dzieci z pierwszego małżeństwa"39. Są to o tyle trudne przypadki, że zazwyczaj między małżonkami w chwili podpisywania umowy istnieje napięcie lub nawet konflikt. Oczywiście, obie strony w obecności notariusza muszą wyrazić zgodną wolę zawarcia umowy majątkowej o określonej treści i rejent powinien przekonać się, że decyzja o dokonaniu takiej czynności została podjęta w sposób świadomy, swobodny, bez użycia groźby czy podstępu. Niemniej jednak bywa ona podszyta obawami jednej strony i pretensja żalem drugiej z powodu braku zaufania. Wielokrotnie umowy takie stanowią preludium do wystąpienia z pozwem o rozwiązanie małżeństwa przez rozwód. W literaturze wskazuje się nieprozumienia na tle finansowym jako jedną z głównych przyczyn rozkładu pożycia małżeńskiego i rozwodów ${ }^{40}$.

Jak wskazano powyżej, umowa majątkowa może być przez strony zmieniona lub rozwiązana - jednak konieczne jest w tym wypadku zachowanie formy aktu notarialnego ${ }^{41}$. W ten sposób małżonkowie mają możliwość powrotu do wspólności majątkowej. Mimo to, 78,9\% ankietowanych notariuszy wskazało, że z możliwości tej małżonkowie korzystają rzadko.

\section{Podsumowanie}

Wprowadzenie rozdzielności majątkowej rozluźnia powiązania ekonomiczne między małżonkami. Przez dużą liczbę małżeństw, zwłaszcza z długim stażem, umowa majątkowa postrzegana jest jako dowód braku zaufania lub miłości do współmałżonka ${ }^{42}$. Ustrój rozdzielności majątko-

${ }^{39}$ E. Skowrońska-Bocian, Małżeńskie ustroje..., s. 110, przyp. 3.

${ }^{40}$ M. Kołecka, Zjawisko separacji i rozwodów w Polsce w latach 2000-2009 z uwzględnieniem wojezwództw, [w:] Zagrożenia i problemy wspótczesnej rodziny, red. S. Bębas, Radom 2011, s. 353-354.

${ }^{41}$ Kodeks rodzinny..., red. K. Pietrzykowski, s. 356.

${ }_{42}$ Taka obserwacja została poczyniona przez jednego z ankietowanych rejentów z Łódzkiej Izby Notarialnej. 
wej może sprzyjać życiu małżonków obok siebie, samodzielnej realizacji projektów, zachowaniu autonomii ekonomicznej ${ }^{43}$.

Z drugiej strony zawarcie umowy majątkowej nie oznacza automatycznie rozpadu więzi gospodarczej, a więc istnienia jednej z pozytywnych przesłanek dopuszczalności rozwodu ${ }^{44}$. Na mężu i żonie nadal ciąży wspólny obowiązek wzajemnej pomocy ${ }^{45}$, solidarnego zaspokajania potrzeb rodziny, którą utworzyli ${ }^{46}$, a każdemu z małżonków przysługuje prawo do zamieszkiwania w lokalu partnera.

Ustrój rozdzielności majątkowej wpisuje się w model egalitarnego małżeństwa monogamicznego (małżeństwa partnerskiego) ${ }^{47}$, coraz bardziej preferowanego przez polskie społeczeństwo. Analiza praktyki notarialnej wskazuje na nieustający wzrost liczby umów wprowadzających rozdzielność majątkową. Może to świadczyć o odejściu od tradycyjnego pojmowa-

${ }^{43}$ Zdaniem S. Grzybowskiego system rozdzielności pozbawia związek małżeński głębszej wewnętrznej harmonii. S. Grzybowski, Prawo rodzinne-zarys wykładu, Warszawa 1980, s. 90 i n.

${ }^{44}$ Patrz: System Prawa Prywatnego. Prawo rodzinne..., s. 618-620. Por. K. Gromek, Kodeks rodzinny..., s. 99. Jednak w literaturze pojawiają się poglądy, że nowoczesne i dostosowane do nowych sytuacji społecznych ukształtowanie intercyzy nie tylko wzmacnia więzi małżeńskie, ale także sprzyja intensywnej pracy zawodowej oraz samodzielnej przedsiębiorczości jednego lub obojga małżonków. T. Sokołowski, Swoboda intercyzy..., s. 119. Por. wyrok Sądu Apelacyjnego w Szczecinie z dnia 12 II 2014 r., sygn. akt. I Aca 785/13, LEX nr 1455638: Zmiana w trakcie małżeństwa ustroju majątkowego w formie zawartej przez małżonków umowy w zasadzie nie powinna niczego zmieniać w zakresie praw i obowiązków małżonków, wynikających z art. 23, 27 i $28^{1}$ k.r.o. Zmiana ustroju majątkowego - ze wspólności ustawowej na rozdzielność majątkową - nie może być przyjmowana jako zerwanie więzi gospodarczej; postanowienie NSA w Warszawie z dnia 13 III 2013 r., sygn. akt I GZ 47/13, LEX nr 1302753: Zgodnie z art. 23 ustawy z dnia 25 II 1964 r. - Kodeks rodzinny i opiekuńczy (DzU z 2012 r., poz. 788) małżonkowie są obowiązani do wzajemnej pomocy oraz do współdziałania dla dobra rodziny; z obowiązku tego nie zwalnia drugiego małżonka nawet rozdzielność majątkowa.

${ }^{45}$ Zob. postanowienie NSA w Warszawie z dnia 10 II 2014 r., sygn. akt. I FZ 530/13, LEX nr 1422571: Obowiązek wzajemnej pomocy między małżonkami nie ma charakteru jedynie moralnego. Na jego charakter normatywny wskazuje bowiem art. 23 k.r.o., a ponadto obowiązek ten nie jest uzależniony od rodzaju ustroju majątkowego między małżonkami.

${ }^{46}$ Zob. K. Gromek, Kodeks rodzinny..., s. 105.

${ }^{47} \mathrm{~W}$ literaturze opisano małżeństwo partnerskie, które jako „typ relacji cechuje jednakowe zaangażowanie obojga partnerów zarówno w życie zawodowe, jak i rodzinne [...] Fundamentalne jest tu założenie o równej pozycji kobiety i mężczyzny, a także równych oczekiwaniach wobec wnoszonego wkładu w emocjonalny i ekonomiczny dobrobyt, przy czym potencjalne różnice $\mathrm{w}$ zarobkach nie przekładają się na większe czy mniejsze prawo do decydowania w kwestiach finansowych". W. Śmigielski, Modele życia rodzinnego. Studium demograficzno-społeczne na przykładzie tódzkiej młodzieży akademickiej, Łódź 2014, s. 76-79. 
nia majątku rodziny i próbie jego redefinicji, ustalenia nowych zasad jego funkcjonowania. Nie można wykluczyć, że jeśli ta tendencja się utrzyma, konieczne będzie w przyszłości podjęcie kroków zmierzających do nowelizacji prawa rodzinnego przez dostosowanie go do nowych potrzeb polskiej rodziny ${ }^{48}$. Niewątpliwie zmiana przepisów winna być poprzedzona dogłębną analizą sytuacji nie tylko z punktu widzenia prawnego, ale i gospodarczego, psychologicznego oraz socjologicznego. Ciekawym materiałem badawczym może tu być właśnie praktyka notarialna, której analiza z pewnością dostarczy wielu zajmujących informacji na temat kondycji polskich małżeństw, a także stosunków majątkowych w nich panujących.

\section{Bibliografia}

\section{Źródła}

„Rocznik Statystyczny Rzeczypospolitej Polskiej” [Warszawa] 2014.

\section{Opracowania}

Andrzejewski M., Dolecki H., Haberko J., Lutkiewicz-Rucińska A., Olejniczak A., Sokołowski T., Sylwestrzak A., Zielonacki A., Kodeks rodzinny i opiekuńczy. Komentarz, LEX 2013, nr 152312.

Damasiewicz A., Intercyzy i umowy między konkubentami. Klauzule umowne, Warszawa 2008.

Gromek K., Kodeks rodzinny i opiekuńczy. Komentarz, Warszawa 2013.

Grzybowski S., Prawo rodzinne - zarys wykładu, Warszawa 1980.

Holewińska-Łapińska E., Orzekanie separacji, Warszawa 2006.

Ignaczewski J., Małżeńskie ustroje majatkowe. Art. 31-54 KRO. Komentarz, Warszawa 2008.

Ignaczewski J. (red.), Sąowe Komentarze Tematyczne. Małżeńskie prawo majątkowe, Warszawa 2014.

Jędrejek G., Intercyzy. Pojęcie. Treść. Dochodzenie roszczeń, Warszawa 2011.

Kołecka M., Zjawisko separacji i rozwodów w Polsce w latach 2000-2009 z uwzględnieniem województw, [w:] Zagrożenia i problemy wspótczesnej rodziny, red. S. Bębas, Radom 2011.

Kosek M., Pojęcie rodziny w Kodeksie rodzinnym i opiekuńczym i negatywne skutki jej redefinicji w wybranych aktach prawnych, [w:] W trosce o rodzinę. Ksiegga pamiatkowa ku czci Profesor Wandy Stojanowskiej, Warszawa 2008.

Łączkowska M., Stosunki majątkowe między przedsiębiorca i jego matżonkiem w świetle ustroju wspólności ustawowej, Warszawa 2006.

Łukasiewicz J. M., Małżeńska wspótzależność majątkowa w polskim prawie cywilnym, Warszawa 2013.

${ }^{48}$ Na konieczność dostosowania prawa do zmian społeczno-gospodarczych zwraca uwagę również G. Jędrejek, Intercyzy. Pojęcie..., s. 78. 
Łukasiewicz J. M. (red.), Instytucje prawa rodzinnego, Warszawa 2014 [LEX nr 205309].

Marszałkowska-Krześ E., Postępowanie nieprocesowe w sprawach osobowych $i$ rodziny, Wrocław 2012.

Miczyńska-Kowalska M., Konsumpcyjny charakter rodziny w społeczeństwie ponowoczesnym, [w:] Małżeństwo i rodzina w ponowoczesności. Szanse - zagrożenia - patologie, red. W. Muszyński, E. Sikora, Toruń 2008.

Pietrzykowski K. (red.), Kodeks rodzinny i opiekuńczy. Komentarz, Warszawa 2015.

Pokora A., Odpowiedzialność majątkowa małżonków i przymusowe dochodzenie od nich roszczeń, Warszawa 2014.

Skowrońska-Bocian E., Matżeńskie ustroje majątkowe, Warszawa 2010.

Skowrońska-Bocian E., Rozliczenia majątkowe mał̇̇onków w stosunkach wzajemnych i wobec osób trzecich, Warszawa 2005.

Smyczyński T. (red.), System Prawa Prywatnego. Prawo rodzinne i opiekuńcze, t. XI, Warszawa 2014.

Sokołowski T., Swoboda intercyzy. Zakres modyfikacji małżeńskich ustrojów majątkowych, Warszawa 2013.

Śmigielski W., Modele życia rodzinnego. Studium demograficzno-społeczne na przykładzie tódzkiej młodzieży akademickiej, Łódź 2014.

\section{ANKIETA}

1. Liczba umów majątkowych małżeńskich zawieranych w Pani Notariusz/Pana Notariusza Kancelarii Notarialnej w ciągu ostatnich lat (biorąc pod uwagę okres do pięciu lat wstecz)...

- wzrosła

- zmalała

- jest ciagle na tym samym poziomie

Jakie umowy majątkowe są najczęściej zawierane w Pani Notariusz/Pana Notariusza Kancelarii Notarialnej?

- umowy wprowadzające rozdzielność majątkową

- umowy wprowadzające rozdzielność majątkową z wyrównaniem dorobku

- umowy wprowadzające wspólność umowną

2. Kiedy najczęściej zawierane są umowy majątkowe wprowadzające rozdzielność majątkową małżeńską?

- już w czasie trwania związku małżeńskiego

- przed zawarciem związku małżeńskiego

3. Czy w Pani Notariusz/Pana Notariusza ocenie wzrosła w ciągu ostatnich kilku lat (biorąc pod uwagę okres do pięciu lat wstecz) liczba umów majątkowych wprowadzających rozdzielność poprzedzających zawarcie związku małżeńskiego? 
- tak

- nie

- pozostaje na tym samym poziomie

4. Jakie są najczęstsze powody zawarcia umowy majątkowej przez nupturientów? (można wybrać więcej niż jedną odpowiedź)

- planowana lub prowadzona przez nich/jedno z nich ryzykowna działalność gospodarcza

- potrzeba samodzielności i niezależności finansowej

- chęć samodzielnego zarządzania swoimi środkami majątkowymi, bez potrzeby porozumiewania się z małżonkiem/małżonką

- odpowiadające obu stronom uzgodnienie, że wszelkie koszty są przez nich dzielone na pół

- zabezpieczenie się przed trudnym podziałem majątku, w przypadku, gdyby doszło do rozwodu

- inne

5. Na przestrzeni kilku ostatnich lat (biorąc pod uwagę okres do pięciu lat wstecz) umowy majątkowe wprowadzające rozdzielność majątkową częściej podpisują małżonkowie...

- pozostający długo w związku małżeńskim (dziesięć lat i więcej)

- pozostający krótko w związku małżeńskim (do dziesięciu lat)

6. Jakie są powody podpisywania umowy majątkowej małżeńskiej wprowadzającej rozdzielność majątkową przez osoby pozostające w związku małżeńskim?

- powody związane z działalnością gospodarczą (w tym potrzeba zaciągnięcia kredytu, pożyczki na rozpoczęcie lub rozwój działalności gospodarczej)

- potrzeba samodzielności i niezależności finansowej, samodzielnego zarządzania posiadanymi środkami majątkowymi i decydowania o ich konsumpcji

- braku zaufania do rodzaju i sposobu prowadzonej przez współmałżonka działalności zawodowej, wydawania pieniędzy

- brak zaufania do osoby współmałżonka, poczucie zagrożenia przed ekonomicznym wykorzystaniem

- konflikt między małżonkami

- usankcjonowanie istniejącego rozkładu więzi gospodarczej przed, a nawet już w trakcie postępowania o rozwód

- planowane przysporzenie od rodziców jednego z małżonków tylko na rzecz ich dziecka (darowizna działki, mieszkania etc.)

- inne

7. Czy, według Państwa wiedzy, małżonkowie, którzy podpisali umowę wprowadzającą rozdzielność majątkową, wracają do ustroju wspólności?

- nigdy

- rzadko

- często 
8. Bardzo proszę o uwagi, opinie dotyczące tego, jak problemy współczesnych małżeństw odzwierciedlają się w zawieranych umowach majątkowych.

9. Bardzo proszę o wskazanie ciekawych kazusów, przy zachowaniu należytej anonimizacji stron. 